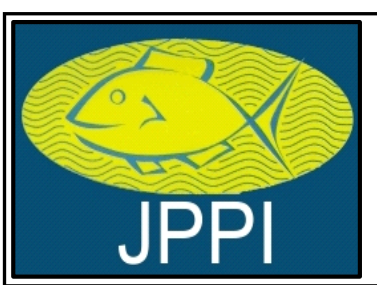

Tersedia online di: http://ejournal-balitbang.kkp.go.id/index.php/jppi

e-mail:jppi.puslitbangkan@gmail.com

JURNAL PENELITIAN PERIKANAN INDONESIA

Volume 25 Nomor 4 Desember 2019

p-ISSN: 0853-5884

e-ISSN: 2502-6542

Nomor Akreditasi RISTEKDIKTI: 21/E/KPT/2018

\title{
DINAMIKA PERIKANAN PAYANG DI PERAIRAN UTARA KARAWANG DAN SEKITARNYA
}

\section{THE DYNAMIC OF PELAGIC SEINERS IN NORTH KARAWANG AND ITS SURROUNDING WATERS}

\author{
Mohammad Adha Akbar ${ }^{\star 1,2}$ dan Mufti Petala Patria ${ }^{3}$ \\ ${ }^{1}$ Program Magister Sains, Sekolah Ilmu Lingkungan, Universitas Indonesia, \\ JI. Salemba Raya No. 4, Lt. 5, Jakarta-10430, Indonesia \\ ${ }^{2}$ Pusat Riset Perikanan, Gedung BRSDM KP, Lt, II, JI. Pasir Putih II, Ancol Timur, Jakarta Utara-14430, Indonesia \\ ${ }^{3}$ Departemen Biologi, Fakultas Matematika dan Ilmu Pengetahuan Alam, Universitas Indonesia, \\ JI. Lingkar Kampus Raya, Pondok Cina, Kecamatan Beji, Kota Depok, Jawa Barat-16424, Indonesia \\ Teregistrasi I tanggal: 26 Juni 2019; Diterima setelah perbaikan tanggal: 09 Januari 2020; \\ Disetujui terbit tanggal: 03 Februari 2020
}

\begin{abstract}
ABSTRAK
Perikanan skala kecil terutama perikanan payang merupakan salah satu tulang punggung mata pencaharian masyarakat pesisir di perairan Karawang, Jawa Barat. Peran nyata aktivitas perikanan pada keanekaragaman sumberdaya hayati laut adalah memanfaatkan sumberdaya hayati perairan laut di kawasan pesisir dengan kondisi kelimpahan sumberdaya ikan yang cenderung berfluktuasi pada tingkat yang relatif rendah. Penelitian dilakukan melalui survey lapang pada kurun waktu Agustus - Nopember 2018 dengan basis data hasil tangkapan dan upaya penangkapan pada rentang waktu 2016-2018. Beberapa data lingkungan terkait ragam keadaan cuaca yang digambarkan oleh data curah hujan, arah dan kecepatan angin digunakan untuk menggambarkan siklus adaptasi nelayan untuk mempertahankan mata pencariannya. Aktivitas penangkapan menggunakan perahu dengan tonase $<10$ GT dan rerata kekuatan mesin sekitar $20 \mathrm{PK}$, beroperasi dalam skala harian dengan alat penangkapan ikan utama adalah jaring payang. Perkembangan tahunan indeks kelimpahan sumberdaya ikan dengan alat tangkap payang pada kurun waktu 2004-2008 dan 2015-2018 cenderung menurun. Tahun 2004 nilai indeks kelimpahan sumberdaya ikan sebesar $268 \mathrm{~kg} /$ trip menjadi $199 \mathrm{~kg} /$ trip pada 2008 dan terus menipis menjadi sebesar $115 \mathrm{~kg} /$ trip tahun 2018. Hal ini mengindikasikan usaha perikanan cenderung berada pada kondisi tidak berkelanjutan bila tidak dilakukan pengelolaan. Keberlanjutan usaha perikanan masih dapat diharapkan jika dilakukan perubahan terhadap sistem usaha yang lebih bersifat menjadi gabungan individu perahu yang berukuran kecil menjadi usaha kelompok dengan perahu yang berukuran lebih besar diatas 10 GT dengan daerah penangkapan yang lebih jauh.
\end{abstract}

\section{Kata Kunci: Dinamika perikanan; nelayan kecil; keberlanjutan; paying; Ciparage}

\begin{abstract}
One day pelagic seine (payang) fisheries, is one of the backbones of coastal community livelihoods in North Karawang waters, West Java. The significant role of fisheries activities to harvest small pelagic fish resource in coastal areas indicated that the monthly CPUE tend fluctuated and stabil at low level. The study was conducted through a field survey in the period August - November 2018 with a database of catches and efforts from 2016-2018. Some environmental data related to various weather conditions illustrated by rainfall data, wind direction and speed are used to describe the adaptation cycle of fishermen to maintain their livelihoods. Fishing activities using boat with tonnage $<10$ GT and average engine strength of around $20 \mathrm{PK}$, operating on a daily scale with the main fishing gear is payang net. The average annual catch per trip (CPUE) of payang fisheries within period of 2004-2008 to 2015-2018 tend to decrease. In 2004 the CPUE was $268 \mathrm{~kg} /$ trip then 2008 at $199 \mathrm{~kg} / \mathrm{trip}$, and continue to lower index in 2018 of $115 \mathrm{~kg} / \mathrm{trip}$. This indicates that the fishery business is suspected to be in an unsustainable condition if no sustainable management is carried out. Sustainability of the fisheries business can still be expected if changes are made to
\end{abstract}


the business system which is more a combination of individual small-sized boats into group businesses with boats larger than 10 GT with more distant fishing grounds.

\section{Keywords: Fisheries dynamic; one day fishers; sustainability; pelagic seine net; Ciparage}

\section{PENDAHULUAN}

Statistik perikanan tangkap menunjukkan bahwa di pantai utara provinsi Jawa Barat terdapat 10.103 unit perahu terdaftar melakukan penangkapan ikan, yang mana 9.725 unit $(96 \%)$ diantaranya merupakan perahu yang berukuran <10 GT (DJPT, 2017). Dengan hasil tangkapan tanpa membedakan ukuran perahu tercatat sebesar 203.900 ton per tahun dan hampir $85 \%$ nelayan di Indonesia didominasi oleh perikanan skala kecil yang beroperasi di sekitar perairan pantai (Hermawan, 2006). Kontribusi nelayan skala kecil sangat besar dalam produksi perikanan tangkap, namun nelayan skala kecil masih diidentikkan dengan kemiskinan (Elfindri, 2002).

Terdapat kecenderungan rendahnya produksi perikanan tangkap di Kabupaten Karawang disertai dengan banyaknya jumlah rumah tangga perikanan (RTP) khususnya perikanan laut yaitu 1.633 RTP pada tahun 2017 yang didominasi oleh buruh perikanan dan nelayan kecil, dengan kapasitas akses dan modal diduga menyebabkan rendahnya kapasitas operasi penangkapan sehingga berakibat pada rendahnya hasil tangkapan per unit alat tangkap. Hal ini diikuti rendahnya tata kelola perikanan yang tidak sejalan dengan prinsip pengelolaan yang bertanggung jawab semakin menimbulkan ketidak pastian terhadap keberlanjutan. Pemanfaatan sumberdaya ikan di perairan utara Karawang seyogianya tetap memperhatikan kaidah kelestarian agar tetap menghasilkan manfaat ekonomi dan kesejahteraan bagi masyarakat secara berkesinambungan.
Terkait dengan fenomena tersebut penelitian ini ditujukan untuk mengamati keberlanjutan perikanan nelayan skala kecil dengan fokus pada armada perahu dengan alat tangkap payang dengan tujuan utama menangkap ikan pelagis kecil. Beberapa faktor lingkungan yang diduga mempunyai pengaruh terhadap aktivitas penangkapan yaitu pola curah hujan juga dibahas dengan prinsip ketersediaan data terbatas. Hasil penelitian ini diharapkan dapat memberikan informasi dan rekomendasi untuk pengembangan perikanan skala kecil khususnya alat tangkap payang di wilayah perairan Kabupaten Karawang dan sekitarnya.

\section{BAHAN DAN METODE Lokasi Penelitian}

Penelitian dilaksanakan di wilayah Pelabuhan Perikanan (PP) Ciparage, Desa Ciparage Jaya, Kecamatan Tempuran, Kabupaten Karawang - Jawa Barat. (Gambar 1). Pemilihan lokasi penelitian dilakukan dengan pertimbangan bahwa di pelabuhan ini terdapat satu badan usaha kelompok nelayan berbentuk koperasi dengan nama Koperasi Produksi Perikanan Laut (KPPL) Samudera Mulya. Koperasi ini memiliki fasilitas fungsional berupa Tempat Pelelangan Ikan (TPI) sebagai tempat mendaratkan sekaligus menjual ikan hasil tangkapan nelayan melakukan operasi penangkapan diperairan pantai Laut Jawa (< 12 mil) bagian utara Kabupaten Karawang.

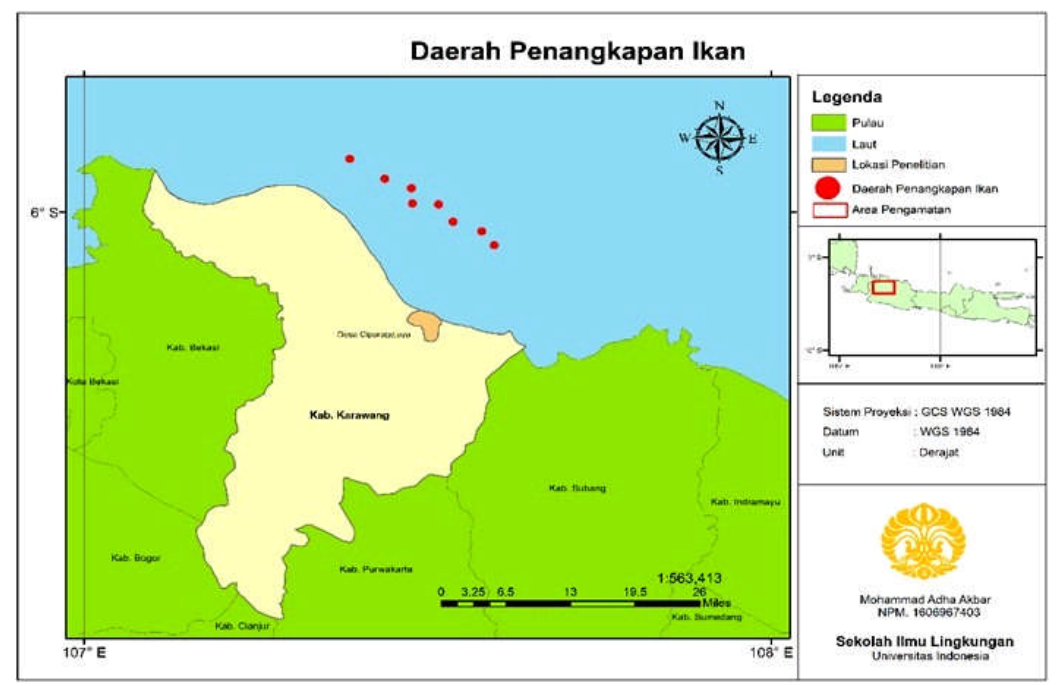

Gambar 1. Peta lokasi penelitian.

Figure 1. Map of research location. 


\section{Pengumpulan Data}

Penelitian ini dilaksanakan selama Agustus-November 2018 dan dilengkapi observasi singkat pada Mei 2019. Beberapa data pendukung dari hasil penelitian sebelumnya dijadikan rujukan untuk mengetahui status dan tren CPUE perikanan payang di lokasi yang relatif sama. Kegiatan yang dilaksanakan yaitu pengumpulan data sekunder, data primer, pengolahan data, analisis data dan penyebaran kuesioner ke nelayan sekaligus wawancara. Sumber data berasal dari data harian tentang upaya penangkapan dan produksi ikan perahu yang berpangkalan di PP. Ciparage, selama kurun waktu 2016-2018. Data pendukung seperti halnya struktur perahu yang terdaftar, curah hujan diperoleh berdasarkan data Dinas Pertanian, Kelautan dan Perkebunan.

\section{Analisis Data}

Untuk mengetahui jumlah unit kapal penangkap dengan alat tangkap jaring payang dan daerah penangkapannya maka dilakukan analisis terhadap jumlah unit kapal penangkap termasuk alat tangkap beserta dimensi dan daerah penangkapannya. Data tersebut berasal dari catatan harian Koperasi Produksi Perikanan Laut (KPPL) Samudera Mulya desa Ciparage Jaya tahun 2016-2018. Tersedianya data jumlah hasil tangkapan dan upaya penangkapan maka analisis dilakukan dengan pendekatan hasil tangkapan per satuan upaya penangkapan atau umum dikenal sebagai catch per unit effort (CPUE) dengan menstandarkan armada penangkapan dalam satuan trip. Besaran nilai CPUE dapat digunakan sebagai indikator tingkat efisiensi dari upaya penangkapan. Secara ringkas perhitungan tersebut mengikuti persamaan Catch Per Unit Effort atau CPUE (Sparre\& Venema, 1999) untuk setiap trip penangkapan.

$$
\text { CPUE }=\frac{\text { Catch }}{\text { Effort }}
$$

dimana:

CPUE = hasil tangkapan per satuan upaya (ton/trip)

Catch = hasil tangkapan (ton)

Effort = jumlah upaya penangkapan (trip)

Untuk mengetahui komposisi hasil tangkapan ikan nelayan di desa Ciparage Jaya maka dilakukan analisis terhadap seluruh jumlah hasil tangkapan armada jaring payang beserta komposisi dan jenis ikan yang didaratkan kemudian diperlihatkan dalam bentuk analisis deskriptif melalui pendekatan grafikal.
Analisis pola musim penangkapan ikan menggunakan metode presentase rata-rata yang didasarkan pada analisis runtun waktu. Prosedurnya adalah sebagai berikut (Purwasasmita 1993): Menghitung nilai hasil tangkapan per upaya tangkap (CPUE = catch per unit of effort) per bulan (Ui) dan rata-rata bulanan CPUE dalam setahun (Û).

$$
\hat{U}=\frac{1}{m} \sum_{i=1}^{m} U i
$$

dimana:

$\hat{U}=$ CPUE rata-rata bulanan dalam setahun (ton/ trip)

$\mathrm{Ui}=$ CPUE per bulan (ton/trip)

$\mathrm{m}=12$ (jumlah bulan dalam setahun)

Menghitung Up yaitu rasio Ui terhadap Û dinyatakan dalam persen

$U p=\frac{U i}{\hat{U}} X 100 \%$

Selanjutnya menghitung indeks musim (IM).

$I M i=\frac{1}{t} \sum_{i-1}^{t} U P$

dimana:

IMi = Indek musim ke i

$\mathrm{t} \quad=$ Jumlah tahun dari data

Jika jumlah IMi tidak 1200\% (12 bulan x $100 \%$ ), maka diperlukan penyesuaian dengan rumus sebagai berikut;

$$
I M S i=\frac{1200}{\sum_{i=1}^{m} I M 1} x I M i
$$

dimana:

$\mathrm{IMSi}=$ Indek musim ke I yang disesuaikan

Jika dalam perhitungan terdapat nilai ekstrim pada Up, maka nilai Up tidak digunakan dalam perhitungan nilai indeks musim (IM), yang digunakan adalah median (Md) dari IM tersebut. Jika jumlah nilai Md tidak sebesar $1200 \%$, maka perlu dilakukan penyesuaian sebagai berikut:

$$
I M M D S i=\frac{1200}{\sum_{i=1}^{m} M d 1} x \text { Mdi }
$$

dimana:

IMMDSi = Indek musim dengan median yang disesuaikan ke i 
Kriteria penentuan musim ikan adalah jika indeks musim lebih dari 1 (lebih dari 100\%) atau di atas ratarata; dan bukan musim jika nilai indeks musim kurang dari 1 (kurang dari 100\%). Jika IM = 1 (100\%), nilai ini sama dengan harga rata-rata bulanan sehingga dapat dikatakan dalam keadaan normal atau berimbang. Penggolongan musim penangkapan ikan dapat dibedakan dalam 3 (tiga) kategori berdasarkan nilai indeks musim penangkapan (IMP) yaitu musim paceklik, musim sedang, dan musim puncak (Zulkarnain et al., 2012).

Untuk menghitung hubungan hasil tangkapan dan curah hujan dilakukan dengan analisis regresi linear sederhana. Analisis regresi merupakan salah satu teknik analisis data dalam statistika yang seringkali digunakan untuk mengkaji hubungan antara beberapa variabel dan meramal suatu variabel. Variabel dependent yang digunakan dalam penelitian ini yaitu hasil yang tangkapan, sedangkan untuk variabel independent yaitu curah hujan. Persamaan regresi tersebut adalah:

$Y=a+b X$

dimana:

$\mathrm{Y}=$ hasil tangkapan

$\mathrm{X}=$ curah hujan

$\mathrm{a}=$ intersep/konstanta

$\mathrm{b}=$ koefisien regresi curah hujan

Uji F dilakukan untuk menguji pengaruh variabel bebas (independent) secara bersama terhadap variabel tidak bebas (dependent) atau ketepatan model. Dari tabel Anova didapatkan nilai significance $F$, jika nilai $F$ hitung lebih kecil dari nilai $F$ tabel pada taraf kepercayaan $95 \%$ berarti nyata dan jika lebih besar dari $\mathrm{F}$ tabel pada taraf kepercayaan $95 \%$ berarti tidak nyata. Sedangkan Uji t dilakukan untuk mengetahui taraf signifikansi variabel dependen.

\section{HASIL DAN BAHASAN \\ Hasil}

\section{Dinamika Pemanfaatan Sumberdaya Ikan}

Kabupaten Karawang merupakan salah satu daerah perikanan rakyat di Provinsi Jawa Barat yang sebagian wilayahnya ada di pesisir pantai sehingga kehidupan masyarakatnya sebagian besar berprofesi sebagai nelayan. Secara geografis Kabupaten Karawang terletak antara: 1070ㅜ $-107^{\circ} 40$ Bujur Timur dan 556، $-6034^{\prime}$ Lintang Selatan dengan luas wilayah 1.753,27 $\mathrm{km} 2$ atau 3,73 persen dari luas Provinsi Jawa Barat (BPS, 2017). Jumlah rumah tangga perikanan (RTP) tangkap khususnya perikanan laut kabupaten Karawang tahun 2017 berjumlah 1.633 RTP, jumlah ini menempati urutan kelima terbanyak dari $11 \mathrm{Kabupaten/Kota} \mathrm{yang} \mathrm{memiliki} \mathrm{wilayah} \mathrm{pesisir}$ di Provinsi Jawa Barat. Produksi perikanan tangkap di Kabupaten Karawang memberikan kontribusi terbesar keempat yaitu 8.681,36 Ton dari total jumlah produksi perikanan tangkap Jawa Barat (BPS Provinsi Jawa Barat, 2017).

Pengamatan terhadap aktivitas perahu selama penelitian pada Agustus - Desember 2018 memperlihatkan bahwa dari jumlah kapal terdaftar sebanyak 93 unit dengan ukuran tonase perahu didominasi (95\%) oleh 4-5 GT (Gambar 2). Dimensi perahu berkisar pada ukuran panjang $6-12 \mathrm{~m}$, lebar 2,3-4 $\mathrm{m}$ dan tinggi $0,5-1,5 \mathrm{~m}$.

Mengacu pada Undang Undang No 7 Tahun 2016 tentang Perlindungan dan Pemberdayaan Nelayan, Pembudidaya Ikan, dan Petambak Garam, sebaran bobot perahu menunjukkan bahwa aktivitas perikanan dikategorikan sebagai nelayan kecil dengan perahu berukuran < 10 GT. Dari 93 unit perahu terdaftar terdapat sebanyak $58-73$ unit perahu aktif atau berkisar antara $62-78 \%$ melakukan penangkapan ikan (Gambar 3).

Frekuensi aktivitas penangkapan (trip) selama periode Agustus - Desember 2018 memperlihatkan bahwa rerata trip dalam 1 bulan berkisar antara $6.4-$ 8.4 trip/bulan dengan maksimum $22-26$ trip (Tabel 1).

Sebaran trip bulanan memperlihatkan bahwa sebagian besar ( $31-59 \%)$ perahu melakukan aktivitas penangkapan kurang dari 5 trip/bulan. Kelompok perahu yang melakukan aktivitas penangkapan 5 10 trip/bulan sebesar $22-34 \%$, kelompok $10-15$ trip sebesar $11-31 \%$ dan kelompok $15-20$ hari sebesar $2-13 \%$, sedangkan kelompok $>20$ hari sebesar kurang dari $5 \%$ setiap bulan (Gambar 4). 


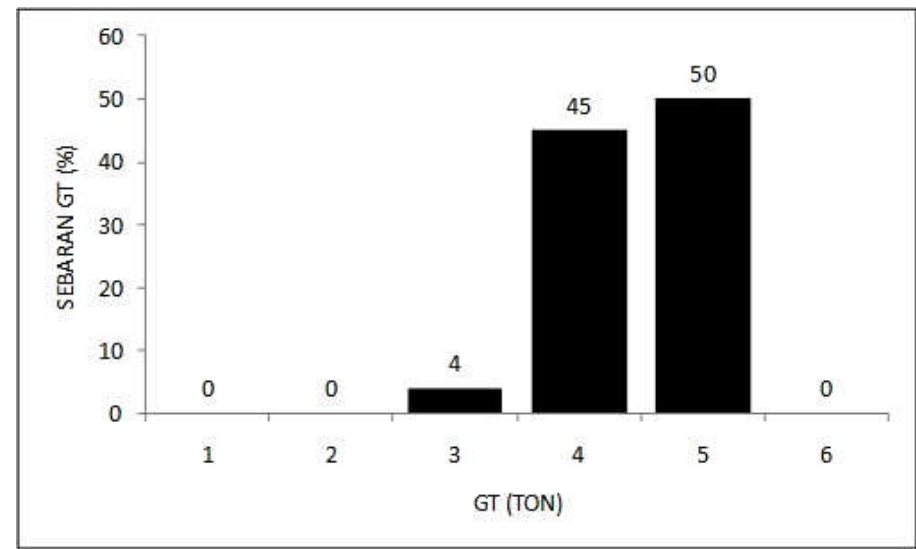

Gambar 2. Sebaran ukuran perahu (GT) di PP. Ciparage. Figure 2. Boat size distribution (GT) in PP. Ciparage.

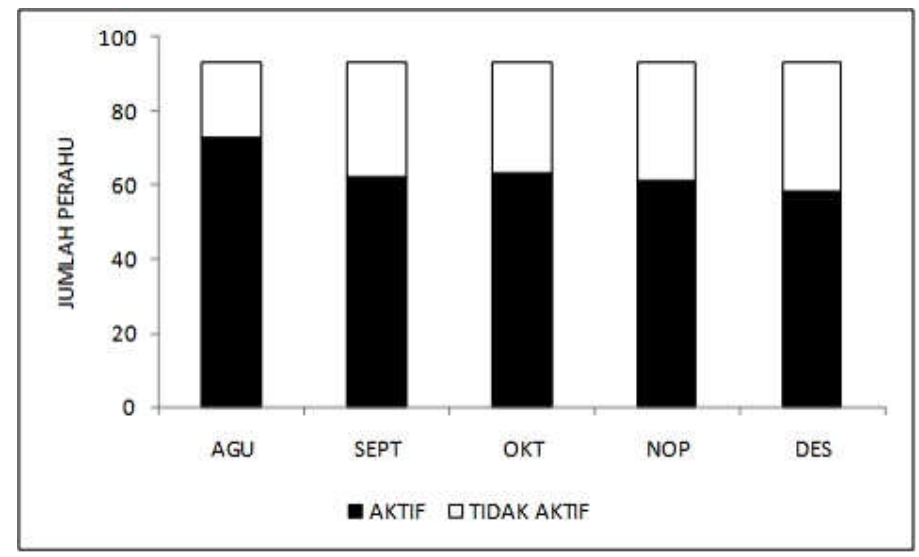

Gambar 3. Perahu aktif yang berpangkalan di PP. Ciparage Agustus - Desember 2018.

Figure 3. Active fishing boats in PP. Ciparage during August-December 2018.

Tabel 1. Jumlah trip maksimum, minimum, rata rata dan simpangan baku trip

Table 1. Number of trips, maximum, minimum, average and standard deviation

\begin{tabular}{cccccc}
\hline & Agustus & September & Oktober & Nopember & Desember \\
\hline Maks & 26.0 & 22.0 & 23.0 & 24.0 & 24.0 \\
Min & 1.0 & 1.0 & 1.0 & 1.0 & 1.0 \\
Rata rata & 6.4 & 7.4 & 8.4 & 8.4 & 8.3 \\
Stdev & 6.1 & 5.4 & 5.8 & 6.1 & 4.9 \\
\hline
\end{tabular}

Sumber: hasil olahan data peneliti, 2018 


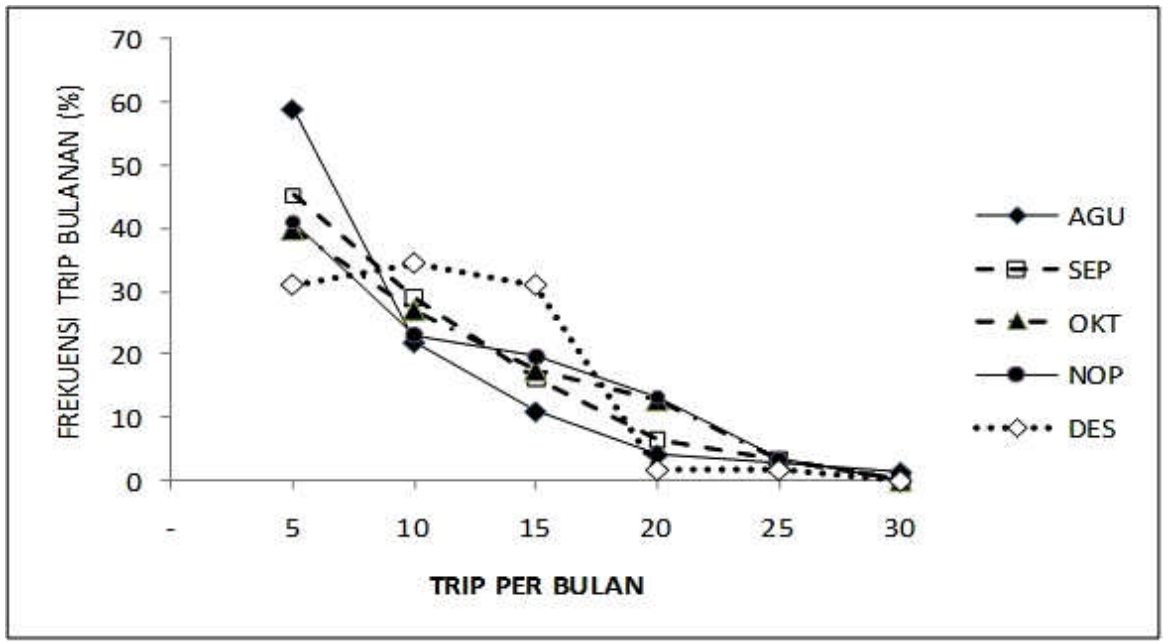

Gambar 4. Sebaran frekuensi trip bulanan pada Agustus - Desember 2018.

Figure 4. Frequency distribution of monthly of trips on August-Desember 2018.

Hal ini menunjukkan bahwa aktivitas penangkapan sebagian besar berada pada kelompok kurang dari 5 trip atau 5 hari dalam 1 bulan. Hasil wawancara tentang pola sebaran spesifikasi dan dimensi perahu aktif yang terkategori nelayan kecil, frekuensi penangkapan yang relatif terbatas diperoleh informasi bahwa keterbatasan modal operasional, keadaan cuaca dan peluang keberhasilan penangkapan berpengaruh pada pengambilan keputusan melakukan operasi penangkapan.
Terdapat berbagai alat tangkap yang beroperasi di wilayah utara Karawang. Jumlah alat penangkapan ikan yang beroperasi di perairan utara Karawang dan mendaratkan hasil tangkapannya di KPPL Samudera Mulya tahun 2017 sebanyak 196 unit alat tangkap, yang terdiri atas alat tangkap jaring payang sebanyak 158 unit, jaring bondet sebanyak 26 unit dan jaring rampus sebanyak 12 unit (Gambar 5).

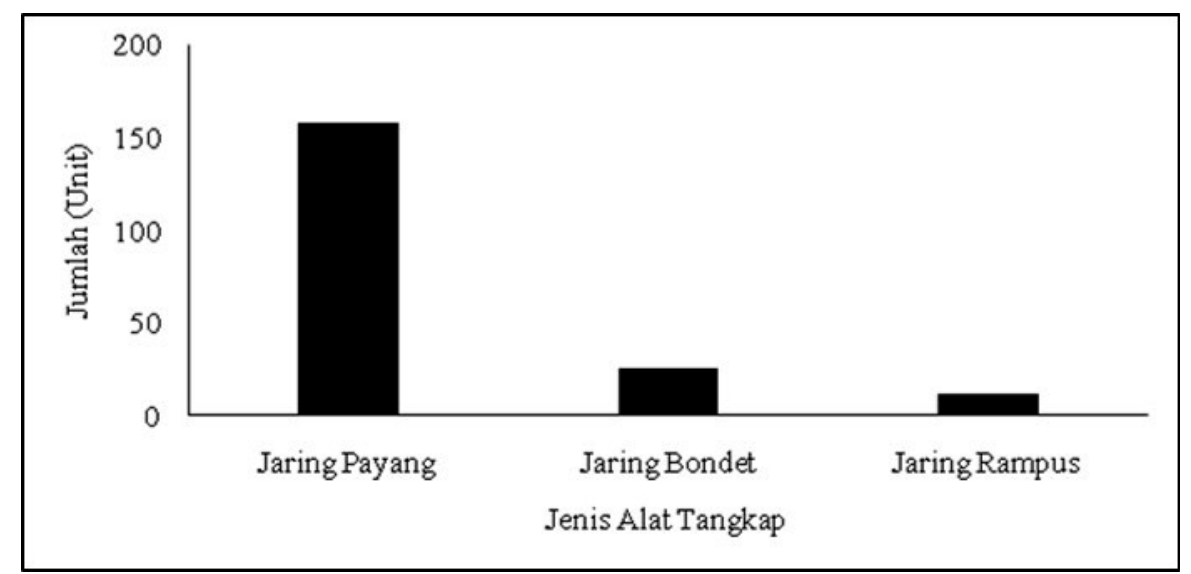

Gambar 5. Jumlah dan Jenis Alat penangkapan ikan di PP. Ciparage.

Figure 5. Number and Types of Fishing Gears in PP. Ciparage.

\section{Komposisi dan Jenis Ikan Hasil Tangkapan}

Komposisi hasil tangkapan jaring payang di Desa Ciparage terdiri atas jenis ikan pelagis kecil diantaranya teri nasi, teri, tembang, layur, selar dan kembung dengan persentase hasil tangkapan tertinggi sebesar $68 \%$, ikan demersal (Bawal, Kakap) 22\%, cumi $6 \%$ dan ikan pelagis besar (tenggiri, tongkol dan kuwe) 4\% (Gambar 6).
Dua jenis ikan kelompok pelagis kecil yang didaratkan dalam jumlah besar dan merupakan tujuan utama penangkapan ikan dengan alat tangkap payang adalah ikan teri (Stolephorus commersonii Lacepède, 1803) dan ikan tembang (Sardinella fimbriata Valenciennes, 1847). Pengukuran langsung terhadap sebaran frekuensi ukuran panjang total (cmTL) ikan teri dari 326 spesimen berkisar pada 5,2-8,0 cmTL dengan rata-rata mendekati modus $(51 \%)$ berada pada ukuran 7,0 cmFL (Gambar 7). 


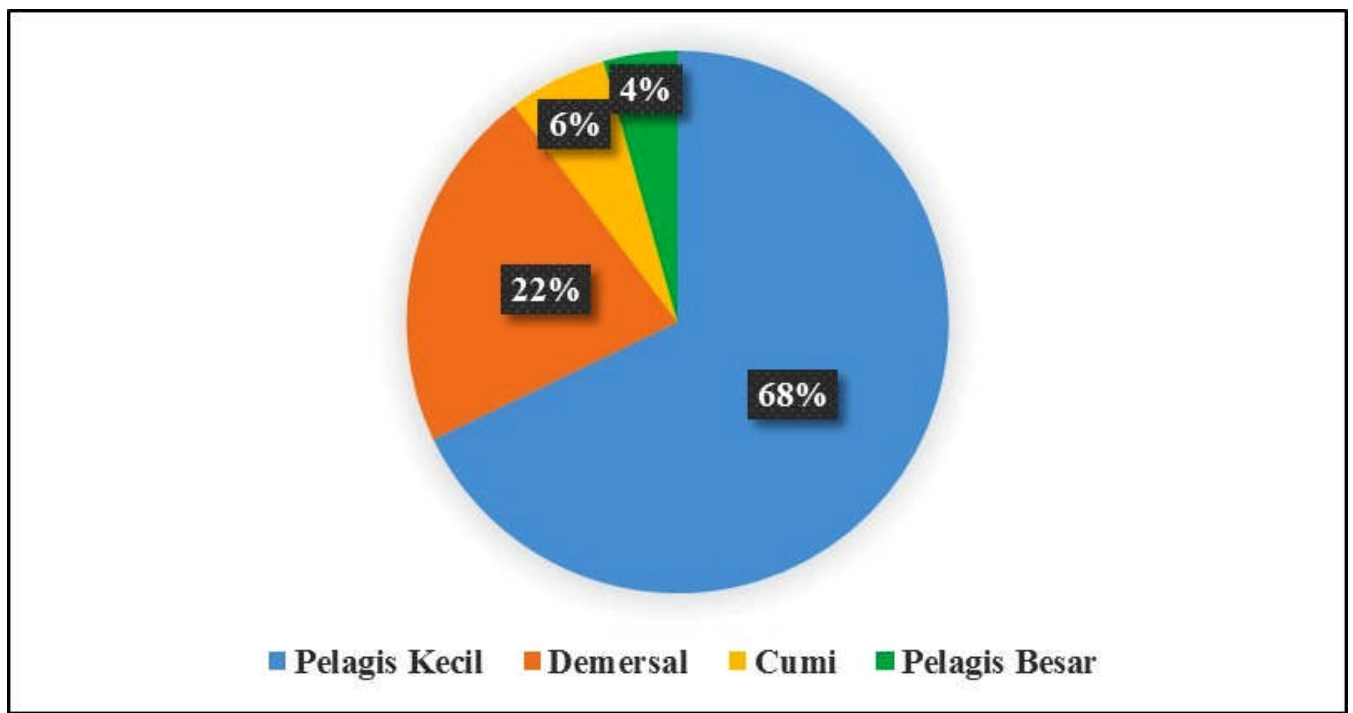

Gambar 6. Komposisi hasil tangkapan ikan nelayan Ciparage Jaya, 2017

Figure 6. Catch composition of fish landed in Ciparage Jaya, 2017.

Sumber: diolah dari data Laporan Tahunan KPPL Samudera Mulya, Karawang Tahun 2017

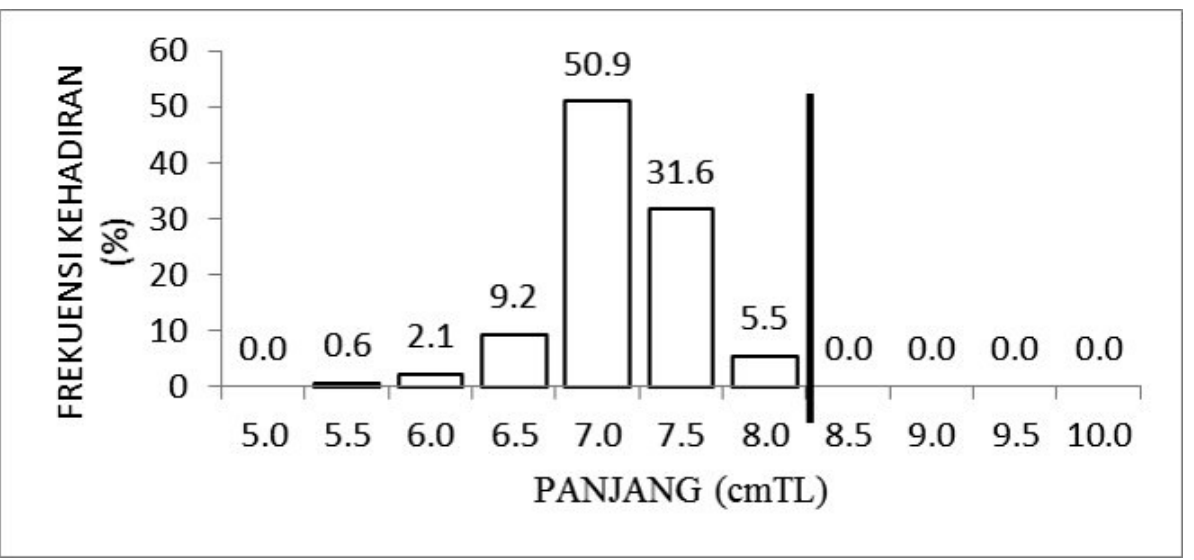

Gambar 7. Sebaran ukuran panjang ikan Teri (Stolephorus commersonii).

Figure 7. Length frequency distribution on achovies (Stolephorus commersonii).

Ket. Garis hitam adalah estimasi ukuran pertama kali berpijah (FishBase)

Remarks: vertical line (black) is the estimate of size at first maturity (FishBase)

Pengamatan langsung terhadap sebaran ukuran ikan tembang memperlihatkan rentang panjang yang berkisar antara $11,0-22,7 \mathrm{cmTL}$ dengan dua modus ukuran pada 13 dan $17 \mathrm{~cm} T L$ dengan rata-rata sebesar 16,1 cmTL (Gambar 8).

\section{Indeks Musim Penangkapan Ikan}

Kajian musim penangkapan ikan menghasilkan informasi mengenai waktu dan atau musim yang paling sesuai bagi nelayan di Desa Ciparage Jaya untuk melakukan aktivitas penangkapan ikan. Melalui hal tersebut, diharapkan operasi penangkapan ikan dapat dilaksanakan dengan efisien, sehingga risiko kerugian masyarakat dalam bisnis penangkapan ikan dapat diminimalkan. Untuk mencapai keuntungan ekonomi secara optimal, maka kegiatan penangkapan ikan harus dilakukan pada saat musim puncak. Hasil analisis indeks musim penangkapan (IMP) ikan tahun 2017 di perairan Karawang dan sekitarnya dapat dilihat pada Gambar 9. 


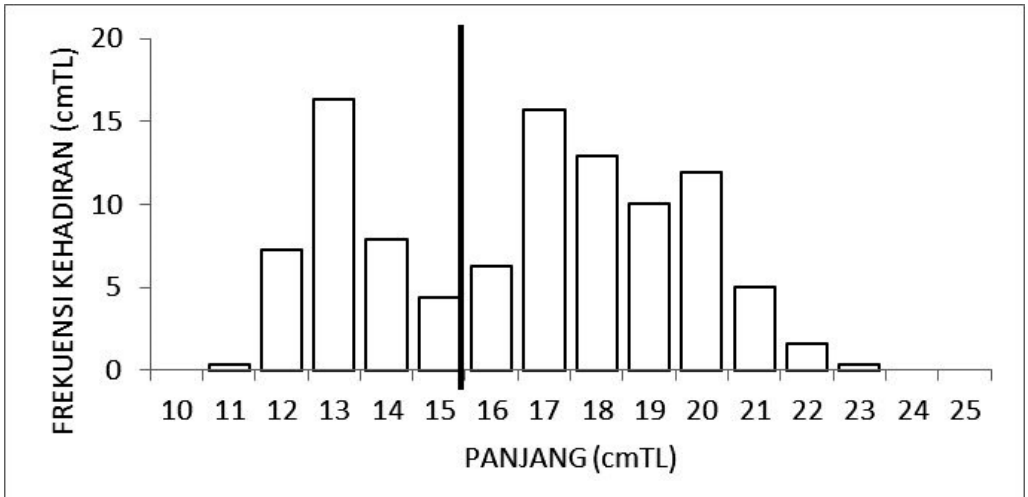

Gambar 8. Sebaran ukuran panjang ikan Tembang (Sardinella fimbriata). Figure 8. Length frequency distribution on Sardine (Sardinella fimbriata). Ket. Garis hitam adalah estimasi ukuran pertama kali berpijah (FishBase) Remarks: vertical line (black) is the estimate of size at first maturity (FishBase)

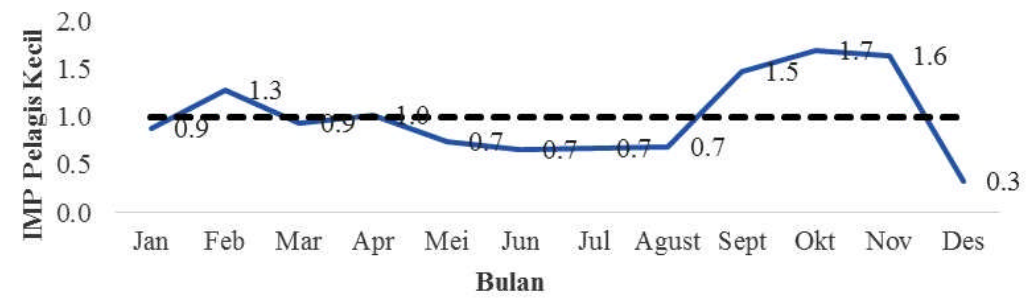

(a)

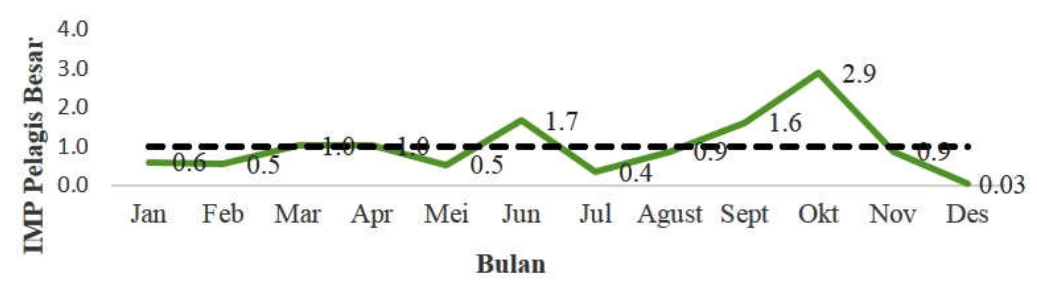

(b)

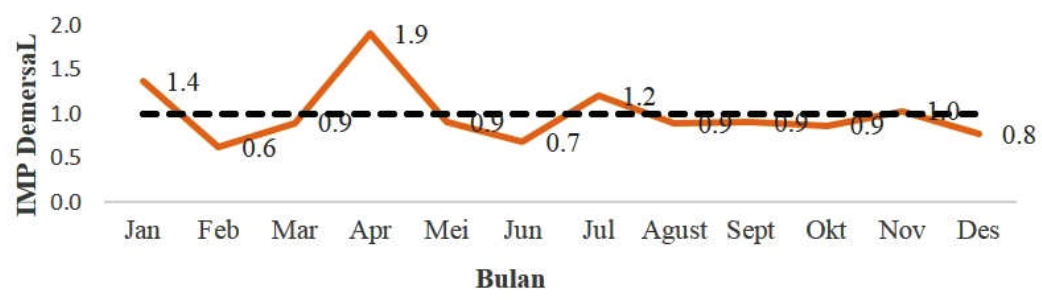

(c)

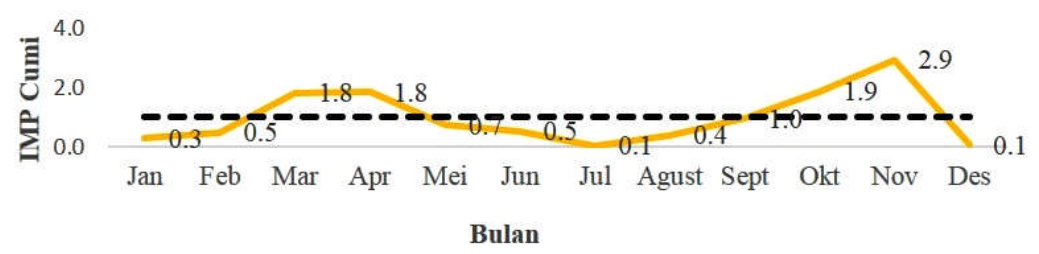

(c)

Gambar 9. Indeks musim penangkapan (IMP) ikan (a) pelagis kecil; (b) pelagis besar; (c) demersal dan (d) cumi dengan alat tangkap payang.

Figure 9. Index of fishing season (IMP) (a) small pelagic fish; (b) large pelagic fish; (c) demersal and (d) squid of payang fishery.

Sumber: diolah dari data Laporan Tahunan KPPL Samudera Mulya, Karawang Tahun 2017 
Grafik diatas menunjukkan bahwa musim penangkapan ikan pelagis kecil terjadi pada Februari, April, September sampai November. Musim puncak terjadi pada Oktober yang ditandai dengan IMP tertinggi. Bukan musim penangkapan ikan pelagis kecil terjadi jika IMP kurang dari 1.0, kondisi ini terjadi pada Januari, Maret, Mei sampai Agustus dan Desember. Musim penangkapan ikan pelagis besar terjadi pada Maret, April, Juni, September,dan Oktober. Musim puncak terjadi pada Oktober. Bukan musim penangkapan ikan pelagis besar terjadi pada Januari, Februari, Mei, Juli, Agustus, November dan Desember. Musim penangkapan ikan demersal terjadi pada Januari, April, Juli dan November. Musim puncakterjadi pada April. Bukan musim penangkapan ikan demersal terjadi terjadi pada Februari, Maret, Mei, Juni, Agustus, September, Oktober dan Desember. Sedangkan musim penangkapan cumi terjadi pada Maret, April, September, Oktober dan November. Musim puncak terjadi pada November. Bukan musim penangkapan cumi terjadi pada januari, Februari, Mei, Juni, Juli, Agustus dan Desember.

\section{Indeks Kelimpahan Sumberdaya Ikan}

Produksi tangkapan ikan dan upaya 2004-2008 cenderung meningkat pada kisaran produksi 2.330-
2950 ton, dengan rata-rata produksi tahun 2004-2008 sebesar 2.686 ton dengan upaya pada kisaran 8.68914.830 trip dengan rata-rata upaya penangkapan sebesar 11.390 trip. Produksi tangkapan dan upaya penangkapan tertinggi terjadi pada tahun 2008 yaitu sebesar 2.950 ton, dengan total upaya yang dilakukan sebesar 14.830 trip. Sedangkan produksi tangkapan terendah terjadi pada tahun 2004 yaitu sebesar 2.330 ton, dengan total upaya 8.689 trip. Upaya penangkapan yang dilakukan 2004-2008 cenderung meningkat

Produksi tangkapan ikan dari tahun 2015-2018 cenderung meningkat pada kisaran 176-896 ton, dengan rata-rata produksi tahun 2015-2018 sebesar 628 ton. Produksi tangkapan tertinggi terjadi pada tahun 2016 yaitu sebesar 896 ton, dengan total upaya yang dilakukan sebesar 6.201 trip. Sedangkan produksi hasil tangkapan terendah terjadi pada tahun 2015 dengan total produksi sebesar 176 ton, dengan total upaya 2.813 trip. Upaya penangkapan yang dilakukan dari tahun 2015-2018 juga cenderung meningkat pada kisaran 2.813-7.787 trip dengan ratarata upaya penangkapan sebesar 5.779 trip (Tabel 2).

Tabel 2. Pendaratan, upaya dan indeks kelimpahan ikan pelagis kecil 2004-2008 dan 2015-2018 di PP Ciparage

Tabel 2. Landing, effort and CPUE of small pelagic fish 2004-2008 and 2015-2018 in PP Ciparage

\begin{tabular}{cccc}
\hline Tahun & $\begin{array}{c}\text { Total Produksi } \\
\text { (Ton) }\end{array}$ & $\begin{array}{c}\text { Upaya } \\
\text { (Trip) }\end{array}$ & $\begin{array}{c}\text { Indeks Kelimpahan } \\
\text { (Ton/Trip) }\end{array}$ \\
\hline 2004 & 2330 & 8689 & 268 \\
2005 & 2442 & 9493 & 257 \\
2006 & 2940 & 11172 & 263 \\
2007 & 2770 & 12767 & 217 \\
2008 & 2950 & 14830 & 199 \\
2015 & 176 & 2813 & 63 \\
2016 & 896 & 6201 & 144 \\
2017 & 715 & 7787 & 92 \\
2018 & 724 & 6315 & 115 \\
\hline
\end{tabular}

Sumber: data tahun 2004-2008 (Anas, $\mathrm{P}$ et al, 2010) dan data 2015-2018 diolah dari data Laporan Tahunan KPPL Samudera Mulya, Karawang Tahun 2015-2018 
Perkembangan indeks tahunan kelimpahan sumberdaya ikan pada kurun waktu tahun 2004-2008 cenderung mengalami penurunan (Gambar 10). Pada tahun 2004 nilai indeks kelimpahan sumberdaya ikan mencapai 268 ton/trip dengan total produksi tangkapan sebesar 2.330 ton dari total upaya 8.689 trip. Tahun 2005 mengalami penurunan nilai indeks kelimpahan sumberdaya ikan menjadi 257 ton/trip dengan total produksi tangkapan sebesar 2.442 ton dari total upaya 9.493 trip. Tahun 2006 nilai indeks kelimpahan sumberdaya ikan mengalami sedikit peningkatan menjadi 263 ton/trip dengan total produksi tangkapan sebesar 2.940 ton dari total upaya 11.172 trip. Tahun 2007 dan 2008 terjadi penurunan nilai indeks kelimpahan sumberdaya ikan menjadi 217 ton/trip dan 199 ton/trip, dengan total produksi masing-masing sebesar 2.770 ton dan 2.950 ton dari total upaya masing-masing sebesar 12.767 trip dan 14.830 trip.
Sedangkan perkembangan indeks kelimpahan sumberdaya ikan pada kurun waktu 2015-2018 berfluktuatif.

Pada tahun 2015 nilai indeks kelimpahan sumberdaya ikan mencapai 63 ton/trip dengan total produksi tangkapan sebesar 176 ton dari total upaya 2.813 trip. Tahun 2016 nilai indeks kelimpahan sumberdaya ikan mengalami peningkatan menjadi 144 ton/trip dengan total produksi tangkapan sebesar 896 ton dari total upaya 6.201 trip. Tahun 2017 kembali mengalami penurunan nilai indeks kelimpahan sumberdaya ikan menjadi 92 ton/trip dengan total produksi tangkapan sebesar 715 ton dari total upaya 7.787 trip. Tahun 2018 mengalami peningkatan nilai indeks kelimpahan sumberdaya ikan menjadi 115 ton/trip dengan total produksi tangkapan sebesar 724 ton dari total upaya 6.315 trip.

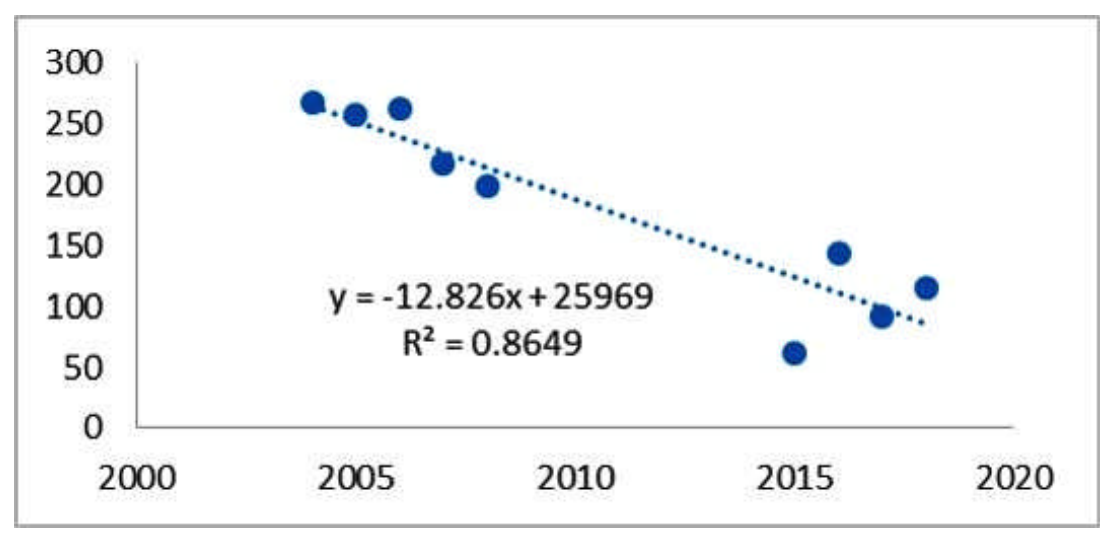

Gambar 10. Trend Indeks kelimpahan tahunan ikan pelagis kecil 2004-2008 dan 2015-2018.

Figure 10. Trend of annual CPUE of small pelagic fish 2004 - 2008 and 2015-2018.

Sumber: data tahun 2004-2008 (Anas, P et al, 2010) dan data 2015-2018 diolah dari data Laporan Tahunan KPPL Samudera Mulya, Karawang Tahun 2015-2018

\section{Hubungan Curah Hujan dan Hasil Tangkapan Ikan}

Hasil observasi memperlihatkan bahwa rata-rata curah hujan di Kabupaten Karawang pada tahun 2017 berkisar antara 2-304 $\mathrm{mm}$ dan rata-rata hari hujan pada tahun 2017 yaitu 7 hari/bulan. Curah hujan tertinggi terjadi pada Februari, sementara curah hujan terendah terjadi pada Agustus. Jika rata-rata curah hujan pada tahun 2017 sebesar 118 mm dijadikan acuan curah hujan normal maka musim hujan terjadi pada November hingga April sedangkan Mei hingga Oktober memasuki musim kemarau (Gambar 11).

Hubungan hasil tangkapan ikan bulanan dengan rata-rata curah hujan bulanan terbagi dalam dua kelompok. Kelompok pertama pada Januari hingga Agustus, hasil tangkapan dan curah hujan memiliki korelasi yang positif artinya jika curah hujan naik maka hasil tangkapan meningkat. Hubungan tersebut terlihat dari hasil regresi yang di peroleh (Tabel 3 ), yaitu:

Analisis dari kelompok pertama memperlihatkan hubungan yang positif, nilai koefisien determinasi $\left(R^{2}\right)$ yang didapat adalah sebesar 0,808 . Nilai ini memperlihatkan bahwa setiap perubahan hasil tangkapan ikan disebabkan oleh curah hujan yaitu sebesar $80,8 \%$. Kelompok kedua dari September hingga Desember, hubungan curah hujan dengan hasil tangkapan terlihat dari hasil regresi yang di peroleh (Tabel 4), yaitu: 


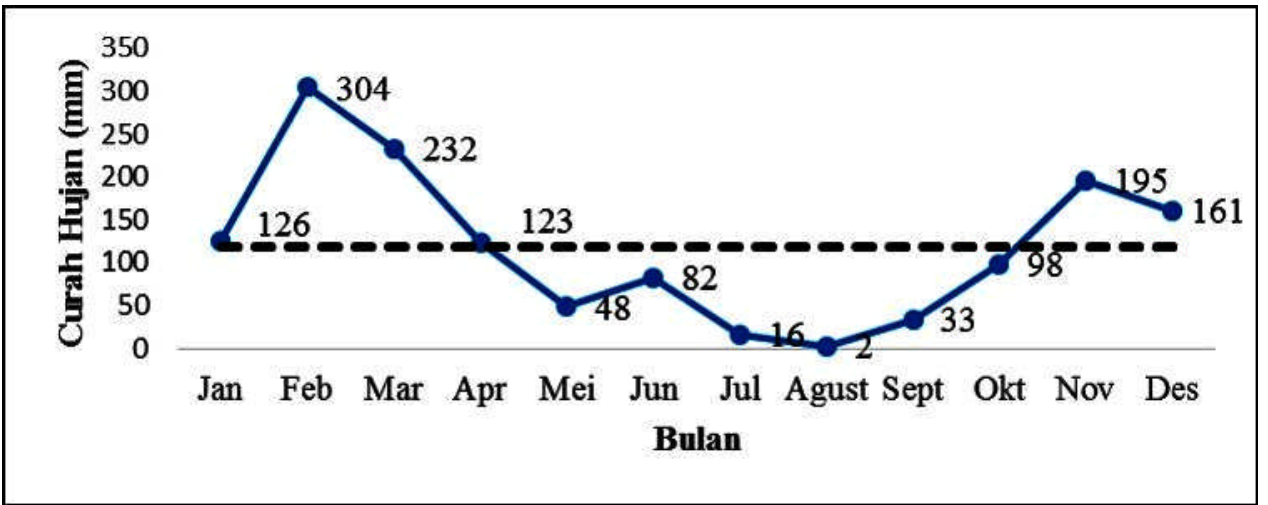

Gambar 11. Rata-rata curah hujan menurut bulan di Kabupaten Karawang, 2017. Figure 11. The monthly average rainfall rate in Karawang district 2017.

Sumber: diolah dari data Badan Pusat Statistik Kabupaten Karawang Tahun 2018

Tabel 3. Hasil regresi curah hujan dan hasil tangkapan ikan kelompok pertama (Januari-Agustus) 2018 Table 3. Result of analysis regression between rainfall and catch (January-August) in 2018

\begin{tabular}{lccccc}
\hline No & Variabel & Koef. regresi & Sig. & P vahe & Kesimpulan \\
\hline 1 Curah hujan & 150.665 & 0.00238 & 0.05 & Sig $<$ P vahue maka signifikan \\
2 Intersep & 39402.098 & & & \\
3 Sig. F & 0.00238 & Sig. F $0.00238<$ P vahue $5 \%$ maka model dapat digunakan \\
$4 \mathrm{R}^{2}$ & 0.808 & & & \\
\hline
\end{tabular}

Sumber: diolah dari data Laporan Tahunan KPPL Samudera Mulya, Karawang Tahun 2017 dan Badan Pusat Statistik Kabupaten Karawang Tahun 2018

Tabel 4. Hasil regresi curah hujan dan hasil tangkapan ikan kelompok kedua (September-Desember) Table 4. Result of analysis regression between rainfall and catch (September-December) in 2018

\begin{tabular}{|c|c|c|c|c|}
\hline No Variabel & Koef regresi & Sig. & $P$ value & Kesimpulan \\
\hline 1 Curah hujan & -93.800 & 0.75959 & 0.05 & $\mathrm{Sig}>\mathrm{P}$ value maka \\
\hline 2 Intersep & 76338.429 & \multirow{3}{*}{\multicolumn{3}{|c|}{$\begin{array}{l}\text { Sig. F } 0.7595>\text { P value } 5 \% \text { maka model tidak dapat } \\
\text { digunakan }\end{array}$}} \\
\hline 3 Sig. F & 0.75959 & & & \\
\hline $4 \mathrm{R}^{2}$ & 0.058 & & & \\
\hline \multicolumn{5}{|c|}{$\begin{array}{ll}\text { Sumber: } & \text { diolah dari data Laporan Tahunan KPPL Samudera Mulya, Karawang Tahun } 2017 \text { dan Badan } \\
& \text { Pusat Statistik Kabupaten Karawang Tahun } 2018\end{array}$} \\
\hline \multicolumn{3}{|c|}{$\begin{array}{l}\text { Hasil analisis pada kelompok kedua } \\
\text { memperlihatkan hubungan yang negatif antara curah } \\
\text { hujan dengan hasil tangkapan ikan, artinya padas aaat } \\
\text { terjadi kenaikan curah hujan hasil tangkapan justru } \\
\text { mengalami penurunan. Hal ini berbanding terbalik } \\
\text { dengan hasil analisis kelompok pertama. Nilai } \\
\text { koefisien determinasi }\left(\mathrm{R}^{2}\right) \text { dari hasil analisis } \\
\text { kelompok kedua sebesar } 0,058 \text {. Nilai ini berarti setiap }\end{array}$} & $\begin{array}{l}\text { perubahan } \\
\text { curah hujan } \\
\text { yaitu sebes } \\
\text { variabel lair } \\
\text { berbagai } k € \\
\text { pada saat } \\
\text { hubungan a } \\
\text { tangkapan }\end{array}$ & $\begin{array}{l}\text { רasil tangkapan ikan yang disebabkan oleh } \\
\text { hanya sebesar } 5,8 \% \text {, sedangkan sisanya } \\
\text { aar } 94,2 \% \text { disebabkan karena variabel- } \\
\text { yang mempengaruhinya namun dengan } \\
\text { terbatasan tidak dilakukan pengukuran } \\
\text { berlangsungnya penelitian. Gambaran } \\
\text { itara curah hujan dengan hasil tangkapan } \\
\text { ikan terlihat pada Gambar } 12 \text {. }\end{array}$ \\
\hline
\end{tabular}




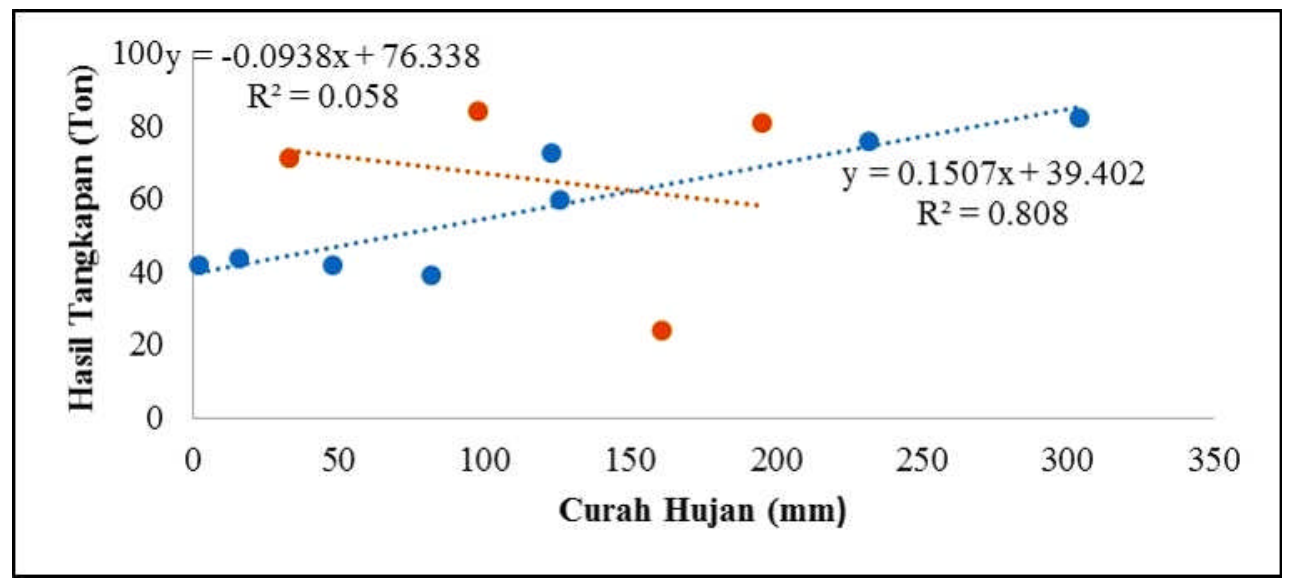

Gambar 12. Hubungan curah hujan bulanan dengan hasil tangkapan ikan bulanan.

Figure 12. Relationship of monthly rainfall rates and catch.

Sumber: diolah dari data Laporan Tahunan KPPL Samudera Mulya, Karawang Tahun 2017 dan Badan Pusat Statistik Kabupaten Karawang Tahun 2018

\section{Bahasan}

Hasil tangkapan alat tangkap payang tertinggi untuk ikan pelagis kecil didominasi oleh jenis ikan tembang, teri dan teri nasi. Hal ini dikarenakan ketersediaan sumberdaya ikan tembang, teri nasi dan teri (Stolephorus spp) di perairan Kabupaten Karawang masih cukup besar sehingga walaupun ukuran ikan kecil tetapi volume hasil tangkapan lebih besar dari jenis ikan-ikan lainnya, ketiga jenis ikan tersebut merupakan target tangkapan utama alat tangkap jaring payang sehingga hasil tangkapannya menjadi besar, ukuran mata jaring (mesh size) kantong pada payang cukup kecil sehingga ketiga jenis ikan tersebut dapat tertangkap. Hal ini sejalan dengan penelitian Tumulyadi et al. (2000) hasil tangkapan payang didominasi oleh jenis ikan teri nasi, dan sebagai ikan sampingan terdiri atas jenis ikan teri, ikan bawal putih (Pampus argenteus), ikan tenggiri (Scomberomorus spp), dan ikan alu-alu (Sphyraenaspp).

Mengacu pada ukuran pertama berpijah ikan teri pada panjang $8,3 \mathrm{cmTL}$ (https://www.fishbase.de/summary/566 diunduh 20 Juni 2019) maka seluruh ikan berada pada fase belum berpijah dan mengindikasikan bahwa penangkapan ikan teri terkategori tidak ramah lingkungan (Sparre \& Venema, 1999) (Gambar 7). Berbeda dengan sifat bioreproduksi ikan terbang yang diindikasikan melalui estimasi ukuran pertama berpijah pada panjang 14,8 cmTL maka ukuran ikan tembang tertangkap sebesar $64 \%$ berada pada ukuran layak tangkap. (https://www.fishbase.de/summary/ 566 diunduh 20 Juni 2019), hal ini menunjukkan bahwa pemanfaatan sumberdaya ikan tembang relatif sehat (Sparre \& Venema, 1999).
Pemanfaatan sumberdaya ikan pelagis kecil di laut Jawa bersifat musiman (Hendiarti et al., 2005) dan sangat terkait dengan pola arus permukaan. Menurut Simbolon et al. (2011) bahwa operasi penangkapan ikan diharapkan hanya dilakukan pada musim puncak, sehingga akan diperoleh hasil tangkapan ikan yang optimum, serta menjaga agar produktivitas sumber daya ikan dapat berkelanjutan dan tetap lestari. Perairan Laut Jawa bagian utara terdiri atas 3 (tiga) musim penangkapan, yaitu musim barat, musim timur dan musim peralihan. Musim barat terjadi pada Desember-Februari, sedangkan musim timur terjadi pada Juni-Agustus. Musim peralihan 1 terjadi pada Maret-Mei, sedangkan musim peralihan 2 (dua) terjadi pada kurun waktu September-November (Arindina, 2014).

Tinggi rendahnya hasil tangkapan ikan diduga berkaitan dengan adanya siklus musim tahunan. Hasil analisis memperlihatkan bahwa rata-rata musim penangkapan ikan jenis pelagis kecil, pelagis besar, demersal dan cumi terjadi pada saat musim peralihan (Maret-Mei dan September-Nopember), hal ini diduga jumlah armada yang beroperasi pada musim peralihan cenderung tinggi dibandingkan pada saat musim barat maupun timur, hal inidikarenakan pada musim peralihan armada lebih sering beroperasi karena keadaan cuaca cukup baikdan gelombang relatif jarang terjadi. Hal sebaliknya terjadi pada saat musim barat maupun timur, rata-rata hasil tangkapan ikan jenis pelagis kecil, pelagis besar, demersal dan cumi cenderung rendah, hal ini diduga jumlah armada yang beroperasi pada musim barat maupun timur cenderung lebih rendah dibandingkan pada saat musim peralihan, hal ini dikarenakan pada musim barat maupun timur kecepatan angin relatif tinggi yang berakibat pada tingginya gelombang sehingga 
sebagian armada tidak melakukan operasi penangkapan ikan.

Pada periode Maret sampai dengan November 2016 trend indeks kelimpahan bulanan sumberdaya ikan relatif stabil dengan fluktuasi yang cukup tinggi dengan rata-rata 0,16 ton/trip. Fluktuasi bulanan nilai indeks kelimpahan sumberdaya ikan sangat terkait dengan perubahan yang nyata upaya penangkapan. Dengan menggunakan rata-rata upaya bulanan sebesar 517 trip sebagai acuan perubahan maka terlihat bahwa upaya pada Januari, Februari dan Desember 2016 berada dibawah rata-rata, sedangkan lainnya berada di atas rata-rata. Besarnya deviasi upaya penangkapan pada Februari dan Juli 2016 terhadap rerata upaya dengan kisaran 373-604 trip/ bulan maka besarnya indeks kelimpahan sumberdaya ikan tertinggi ( 0,17 ton/trip/bulan) terjadi pada April, Juli dan Oktober 2016 dengan upaya penangkapan masing-masing sebesar 499 trip, 378 trip dan 507 trip atau rata-rata sekitar $7,4 \%$ dari total upaya penangkapan 1 (satu) tahun dengan kontribusi hasil tangkapan sebesar 8,9\% dari total hasil tangkapan 1 (satu) tahun, sedangkan besarnya indeks kelimpahan sumberdaya ikan terendah (0,07 ton/trip/bulan) terjadi pada Januari dengan upaya penangkapan sebesar 476 trip atau sekitar $7,7 \%$ dari total upaya penangkapan 1 (satu) tahun dengan kontribusi hasil tangkapan sebesar 3,9\% dari total hasil tangkapan 1 (satu) tahun.

Periode Maret sampai dengan Agustus 2017 trend indeks kelimpahan sumberdaya ikan relatif stabil dengan fluktuasi yang rendah. Dengan menggunakan rata-rata upaya bulanan sebesar 657 trip sebagai acuan perubahan maka terlihat bahwa upaya pada Januari, Februari, Juni, Agustus, September dan Desember 2017 berada dibawah rata-rata, sedangkan bulan lain berada di atas rata-rata. Besarnya deviasi upaya penangkapan pada Februari dan September 2017 terhadap rerata upaya dengan kisaran 424-879 trip/bulan maka besarnya indeks kelimpahan sumberdaya ikan tertinggi (0,19 ton/trip/bulan) terjadi pada Februari dengan upaya penangkapan terendah yaitu 424 trip atau sekitar 5,4\% dari total upaya penangkapan 1 (satu) tahun dengan kontribusi hasil tangkapan sebesar $11,5 \%$ dari total hasil tangkapan 1 (satu) tahun, sedangkan besarnya indeks kelimpahan sumberdaya ikan terendah $(0,05$ ton/trip/ bulan) terjadi pada Desember 2017 dengan upaya penangkapan sebesar 512 trip atau sekitar 6,5\% dari total upaya penangkapan 1 (satu) tahun dengan kontribusi hasil tangkapan sebesar 3,3\% dari total hasil tangkapan 1 (satu) tahun.
Periode Maret sampai dengan Agustus 2018 trend indeks kelimpahan sumberdaya ikan relatif stabil dengan fluktuasi yang rendah dengan rata-rata 0,09 ton/trip. Dengan menggunakan rata-rata upaya bulanan sebesar 526 trip sebagai acuan perubahan maka terlihat bahwa upaya pada Februari, Mei, Juni, Agustus, September, November dan Desember 2018 berada dibawah rata-rata, sedangkan bulan lain berada di atas rata-rata. Besarnya deviasi upaya penangkapan pada Februari dan Juni 2018 terhadap rerata upaya dengan kisaran 378-790 trip/bulan maka besarnya indeks kelimpahan sumberdaya ikan tertinggi $(0,19$ ton/trip/bulan) terjadi pada Oktober dan November 2018 dengan upaya penangkapan masingmasing yaitu 527 trip dan 511 trip atau rata-rata sekitar $8,2 \%$ dari total upaya penangkapan 1 (satu) tahun dengan kontribusi hasil tangkapan sebesar $13,5 \%$ dari total hasil tangkapan 1 (satu) tahun, sedangkan besarnya indeks kelimpahan sumberdaya ikan terendah (0,07 ton/trip/bulan) terjadi pada Agustus dengan upaya penangkapan sebesar 466 trip atau sekitar 7,4\% dari total upaya penangkapan 1 (satu) tahun dengan kontribusi hasil tangkapan sebesar $4,8 \%$ dari total hasil tangkapan 1 (satu) tahun. Fluktuasi tersebut berkaitan dengan parameter yang cukup komplek terutama terkait dengan pola jenis ikan saat merespon perubahan lingkungannya (Brochier et al., 2018). Fenomena puncak musim juga berbeda menurut kawasannya (Irnawati et al., 2018) mengemukakan bahwa msuim penangkapan ikan teri berbeda antara perairan pantai Utara Jawa dan Selat Sunda terjadi pada April sedangkan Agustus di Selatan pulau Jawa. Selanjutnya temuan di perairan yang berbeda (Saraux et al., 2014) menyatakan bahwa kelompok jenis ikan pelagis kecil berkelompok membentuk gerombolan ikan dalam jumlah besar yang umumnya mengikuti pola sebaran spasial dan jenis teri, sardin di perairan bagian utara laut Mediterania membentuk struktur dengan 10 tahunan. Sementara itu fluktuasi kelompok jenis sarden dan ikan teri lebih rumit ketika interqaksi antara sarden dan ikan teri dalam masing-masing sistem dan hubungan empiris dalam jangka panjang dengan perubahan iklim (Lluchcota 2013; Yanez et al., 2017).

Upaya penangkapan yang dilakukan selama kurun waktu 2004-2008 dan 2015-2018 mengalami peningkatan setiap tahunnya, akan tetapi hal ini berbanding terbalik dengan nilai indeks kelimpahan sumberdaya ikan pada kurun waktu tahun 2004-2008 yang cenderung mengalami penurunan setiap tahunnya ditahun yang sama. Sedangkan nilai indeks kelimpahan sumberdaya ikan pada kurun waktu 20152018 berfluktuatif. Hal ini disebabkan karena semakin banyak upaya penangkapan ikan yang dilakukan maka semakin tinggi tingkat eksploitasinya sehingga 
tekanan terhadap sumberdaya ikan akan semakin tinggi. Indeks kelimpahan sumberdaya ikan terendah pada tahun 2015-2018 memperlihatkan kecenderungan penurunan sebesar $76 \%$ dibandingkan kelimpahan tertinggi pada kurun waktu tahun 20042008. Hal ini menunjukan bahwa indeks kelimpahan yang rendah mengakibatkan peluang keberhasilan penangkapan menjadi rendah yang merupakan bagian interdependensi antara sumberdaya ikan dengan perubahan lingkungan.

Hasil wawancara dengan sejumlah nelayan diketahui bahwa terdapat kecenderungan nelayan semakin sulit memperoleh hasil tangkapan ikan, selain itu daerah operasi penangkapan semakin jauh jika dibandingkan dengan 5 tahun sebelumnya. Fenomena ini mengindikasikan bahwa status pemanfaatan sumberdaya ikan semakin tinggi tingkat ekspoitasinya atau ketersediaan sumberdaya ikan yang semakin menurun. Berdasarkan hal tersebut maka usaha perikanan tangkap skala kecil di desa Ciparage masih dapat diharapkan keberlanjutannya jika dilakukan perubahan terhadap sistem usaha yang lebih bersifat menjadi gabungan individu perahu yang berukuran kecil menjadi usaha kelompok dengan perahu yang berukuran lebih besar diatas $10 \mathrm{GT}$ supaya dapat melakukan kegiatan penangkapan di daerah penangkapan yang lebih jauh.

Temuan ini sejalan dengan hasil penelitian Meynecke et al. (2006) yang memaparkan keterkaitan secara signifikan hasil tangkapan ikan yang diperoleh akibat adanya pengaruh curah hujan yang mempengaruhi pola rekruitmen berbagai spesies ikan diwilayah estuari, banyak dari spesies ikan laut bergerak ke arah estuari untuk persiapan pemijahan, menurutnya $30 \%$ hasil tangkapan di kawasan estuaria Queensland Australia dapat diprediksi melalui pola curah hujan. Sehingga pola curah hujan merupakan salah satu komponen iklim yang berpengaruh pada perikanan tangkap. Hal ini didukung oleh pernyataan Hoguane et al., (2012) bahwa pengaruh curah hujan berdampak langsung pada aliran nutrien pada aliran laut yang berdampingan dengan air tawar yang mengalir dari hutan mangrove yang banyak menghasilkan makanan utama dari ikan dan biota perairan. Sedangkan sisanya yaitu sebesar $19,2 \%$ disebabkan karena variabel-variabel lain salah satunya adalah salinitas.

Temuan ini sejalan dengan hasil penelitian Ayub (2010) bahwa ada beberapa penelitian yang memaparkan korelasi negatif dikarenakan faktor curah hujan tidak merupakan faktor tunggal, akan tetapi ada faktor lain yang berpengaruh yaitu ekploitasi yang berlebihan, polusi perairan, reduksi dari aliran air tawar, suhu, salinitas dan pengaruh dari aktivitas penangkapan ikan. Temuan yang dikemukakan oleh tim Balai Riset Perikanan Laut (2004) yang memaparkan bahwa kelimpahan ikan dipengaruhi oleh perubahan lingkungan terutama penyebaran salinitas yang dipengaruhi oleh angin muson. Pada saat ratarata curah hujan di atas normal pergerakan ikan pelagis ke Laut Jawa berkurang akibat pengurangan massa air oseanik di bagian timur Laut Jawa. Terdapat korelasi positif antara hasil tangkapan dengan salinitas permukaan, tetapi korelasi ini menunjukan negatif dengan curah hujan.

\section{KESIMPULAN}

Perkembangan trend indeks kelimpahan sumberdaya ikan pada kurun waktu tahun 2004-2008 dan 2015-2018 rata-rata mengalami penurunan. Tahun 2004 nilai indeks kelimpahan sumberdaya ikan sebesar 268 ton/trip, 2005 sebesar 257 ton/trip, 2006 sebesar 263 ton/trip, 2007 sebesar 217 ton/trip, 2008 sebesar 199 ton/trip. Tahun 2015 sebesar 63 ton/trip, 2016 sebesar 144 ton/trip, 2017 sebesar 92 ton/trip dan 2018 sebesar 115 ton/trip. Berdasarkan hal tersebut maka usaha perikanan tangkap skala kecil di desa Ciparage masih dapat diharapkan keberlanjutannya jika dilakukan perubahan terhadap sistem usaha yang lebih bersifat menjadi gabungan individu perahu yang berukuran kecil menjadi usaha kelompok dengan perahu yang berukuran lebih besar diatas 10 GT dengan daerah penangkapan yang lebih jauh. Hal ini perlu mendapatkan dukungan permodalan dan pelatihan oleh instansi pemerintah pusat maupun daerah. Selain itu perlu adanya dukungan peningkatan kapasitas kelembagaan pengelolaan termasuk pengawasan perikanan melalui kerjasama dan koordinasi yang lebih padu antar kementerian/ lembaga pemerintah pusat, pemerintah daerah dan masyarakat dalam mendukung pengelolaan dan pengawasan perikanan. Sedangkan peningkatan efektifitas penegakan hukum melalui penindakan dan pemberian sanksi yang tegas dan efektif terhadap pelanggar regulasi perikanan tangkap.

\section{PERSANTUNAN}

Penulis mengucapkan terima kasih kepada Dr. Duto Nugroho Peneliti Utama pada Pusat Riset Perikanan atas bimbingannya dalam penulisan ini sehingga tulisan ini dapat diselesaikan. Terima kasih juga disampaikan kepada Bapak Nanang Kosim sebagai administrator Koperasi Produksi Perikanan Laut (KPPL) Samudera Mulya Desa Ciparage Jaya Kabupaten Karawang yang telah membantu dalam pengumpulan data. 


\section{DAFTAR PUSTAKA}

Arindina R. (2014). Keragaan Unit Penangkapan Mini Purse Seine di PPP Lempasing, Bandar Lampung. [Skripsi]. Bogor: Departemen Pemanfaatan Sumberdaya Perikanan, Fakultas Perikanan dan IImu Kelautan, Institut Pertanian Bogor.

Ayub.Z. (2010). Effect of temperature and rainfall as a component of climate change on fish and shirmp catch in Pakistan. The. J. of Transdiciplinary Environmental Studies. 9 (1), 6. p.1-9.

Badan Pusat Statistik Provinsi Jawa Barat (2017). Provinsi Jawa Barat dalam Angka. 716 hal.

Balai Besar Penangkapan Ikan (BBPI) Semarang Tahun 2018.

Balai Riset Perikanan Laut (2004). Laporan Teknis Hasil Penelitian Tahun 2014.

Brochier, T. Auger, P-A., Pecquerie, Machu, E., Capet, X., Thiaw M., Mbaye, B.C., Braham, C. B., Ettahiri, O., Charouki, B., Sene, O. N., Werner F., Brehmer, P. 2018. Complex small pelagic fish population patterns arising from individual behavioural responses to their environment. Progress in Oceanography. 164 (12-27). https://doi.org/10.1016/ j.pocean.2018.03.011

Dinas Kelautan dan Perikanan Kabupaten Karawang Tahun (2017). Rencana Kerja Tahun (2017) dalam Badan Pusat Statistik Kabupaten Karawang Tahun (2018)

Direktorat Jenderal Perikanan Tangkap Tahun 2017. Statistik Perikanan Tangkap Tahun (2017)

Elfindri. (2002). Ekonomi Patron-Client. Fenomena Mikro Rumah Tangga Nelayan dan Kebijakan Makro. Andalas University Press.

Hendiarti, N. Suwarso, Aldrian E., \& Wahyono I. B. (2005). Seasonal variation of pelagic fish catches arround Java. Oceanography 18 (4): 112-123 p.

Hoguane, A.M., Ezidio, D.L.C., \& Tor, G. (2012). Influence of rainfall on tropical coastal artisanal fisheries a case study of Northern Mozambique. J. of Integrated Coastal Zone Management. 12(4):477-482.

Irnawat, R., Surilani D., Susanto A., Munandar A., Rahmawati A. 2018. Potential yield and fishing season of anchovy (Stolephorus spp.) in Banten waters, Indonesia. AACL Bioflux 11(1): 804-809. http://www.bioflux.com.ro/docs/2018.804-809.pdf
Lluch-Cota, S. E. (2013). Modeling sardine and anchovy low-frequency variability. PNAS.110 (33): 13240-13241.

Meynecke, J.O., Shing, Y.L., Norman, C.D., \& Jan, W. (2006). Effect of rainfall as a component of climate change on estuarine fish production in Queensland, Australia. Estuarine, Costal and Shelf Science. 69. p. 491-504.

Purwasasmita R. (1993). musim penangkapan ikan cakalang, katsuwonus pelamis, dengan kapalkapal huhate dan pengaruhnya terhadap peningkatan produksi di Perairan Sekitar Sorong. Jurnal Penelitian Perikanan Laut. 79: 113.

Saraux, C., J Fromentin, J.M., Bigot, J.L., Bourdeix, J.H., Morfin, M., Roos, D., van Beveren, E., Bez, N. (2014). Spatial Structure and Distribution of Small Pelagic Fish in the Northwestern Mediterranean Sea. PLoS ONE 9(11): e111211. https:// doi.org/10.1371/journal.pone.0111211

Simbolon, D., Wiryawan, B., Wahyuningrum, P. I., \& Wahyudi, H. (2011). Tingkat pemanfaatan dan pola musim penangkapan Ikan Lemuru di Perairan Selat Bali. Buletin PSP, 19 (3).

Sparre \& Venema. (1999). Introduction to tropical fish stock assessment. Part 1, Manual. FAO Fisheries Technical Paper No.306/1. Rev.2.438p.

Undang-Undang Nomor 7 tahun 2016 tentang Perlindungan dan Pemberdayaan Nelayan, Pembudi Daya Ikan, dan Petambak Garam

Tumulyadi, A., Purwanti, P., \& Qoid, A. (2000). Intensifikasi alat tangkap payang melalui perbaikan perbandingan gaya apung dan tenggelam yang sesuai, di selat madura, kabupaten Pasuruan. Jurnal IImu-ilmuTeknik, 12(1).10p.

Yanez E., Plaza, F., Sanchez, F., Silva, C., Barbieri, M. A., \& Bohm, G. (2017). Modelling climate change impacts on anchovy and sardine landings in northern Chile using ANNs. Lat. Am. J. Aquat. Res. 45(4): 675-689. http://dx.doi.org/10.3856/ vol45-issue4-fulltext-4

Zulkarnain., Wahju RI., \& Sulistiono. (2012). Komposisi dan Estimasi Musim Penangkapan Ikan Pelagis Kecil dari Purse Seine yang Didaratkan di PPN Pekalongan. Jawa Tengah. Saintek Perikanan. 7(2), 61-70. 